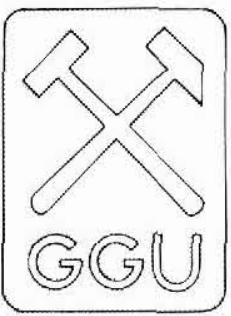

\title{
Ocean Drilling Program (ODP) off South-East Greenland: formation of a volcanic rifted margin
}

\author{
Hans Christian Larsen
}

The exposures of the Tertiary igneous rocks along the East Greenland coast (Fig. 1) have attracted the attention of earth scientists for more than half a century (Wager, 1934; Wager \& Deer, 1938). However, most of the work has concentrated on the petrological and mineralogical aspects of the magmatic rocks (e.g. Skaergaard intrusion). With a few exceptions, such as Brooks (1973), Nielsen (1978), H. C. Larsen (1978), Brooks (1979), Myers (1980) and Nielsen \& Brooks (1981), relatively little attention has been given to the tectonic and plate tectonic setting, mainly because the plate tectonic paradigm did not become accepted until 30 years after Wager and Deer's revolutionary work. Furthermore, the tectonic context of the coastal exposures first becomes really striking when seen together with the geology and structure of the adjacent continental shelf and slope (H. C. Larsen, 1990).

Geophysical data from the East Greenland shelf region gradually became available in the late 1970s and in the $1980 \mathrm{~s}$, in particular through the multi-channel seismic project NAD (H. C. Larsen, 1983a, 1985). From the NAD seismic and aeromagnetic data it became clear that large parts of the East Greenland shelf and slope south of latitude $72^{\circ} \mathrm{N}$ are underlain by a submerged igneous province forming the transition from continental to oceanic crust. One of the most striking features of this igneous complex is the presence of an up to $100 \mathrm{~km}$ wide and generally coast-parallel zone of seaward-dipping reflectors (Figs 1. 2) (H. C. Larsen, 1983b; H. C. Larsen \& Jakobsdóttir, 1988).

During the 1980 s thick and extensive wedges of seaward-dipping reflectors of this kind were reported from a number of rifted margins around the world (Hinz, 1981: Mutter et al., 1982; Smythe, 1983; Coffin \& Eldholm, 1991; Roberts et al., 1991). DSDP and ODP drilling on the Rockall and Voering margins in the North Atlantic (Roberts et al., 1984; Eldholm et al., 1989) has shown that these units comprise subaerially
Fig. 1. Exposure of Tertiary igneous rocks (lavas, central intrusions, dykes and sills) along the east coast of Greenland (black). Igneous rocks offshore (excluding regular oceanic crust) at seabed or below Tertiary sediments are shown by hatched signature (mainly flood basalts). Crosshatching indicates where the offshore igneous rocks show development of seaward-dipping reflectors (see Fig. 2A). Planned ODP drilling transects EG63 and EG66 showr. The northern transect (EG66) is a secondary transect closer to the presumed plume-centre track (IcclandGreenland Ridge). Magnetic chrons A24 through A5 indicated. Detailed drill site location along EG63 transect shown in Figs 2, 3 .

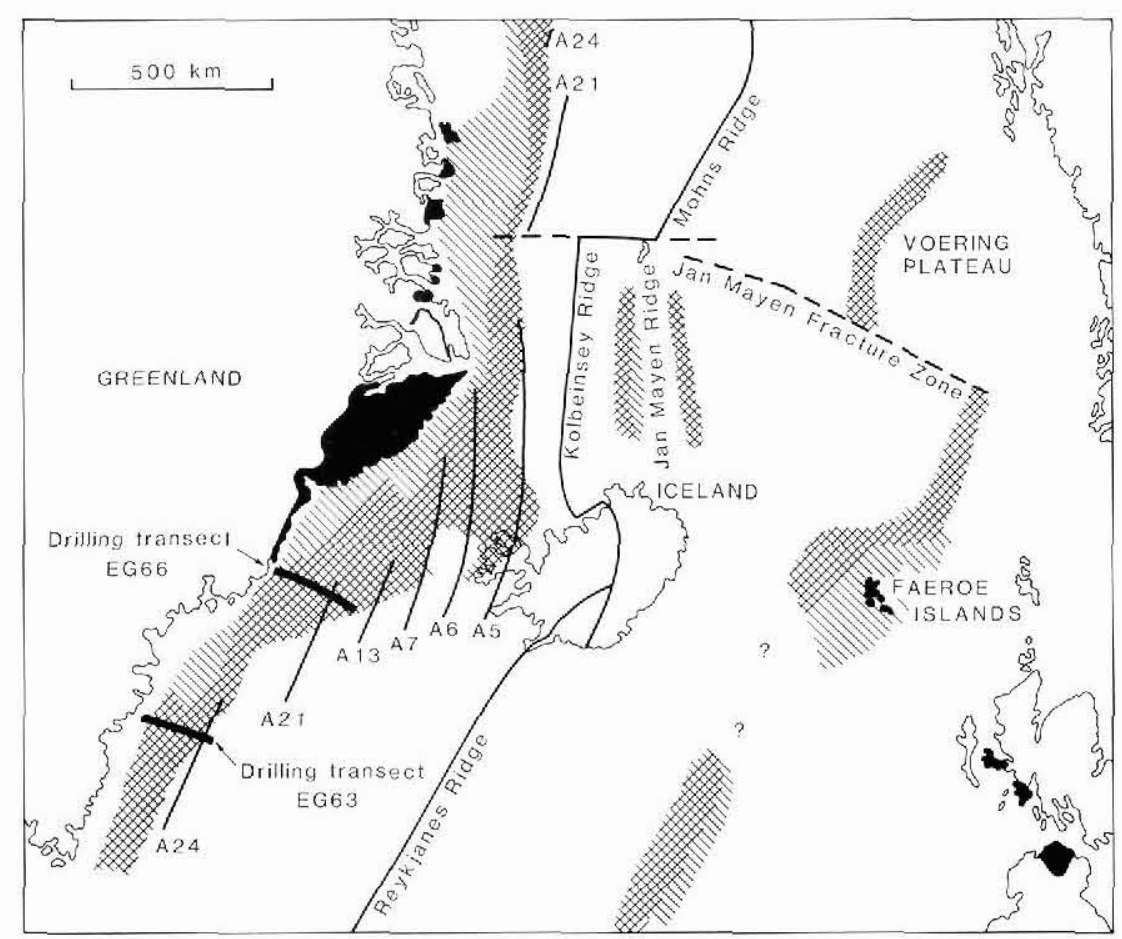



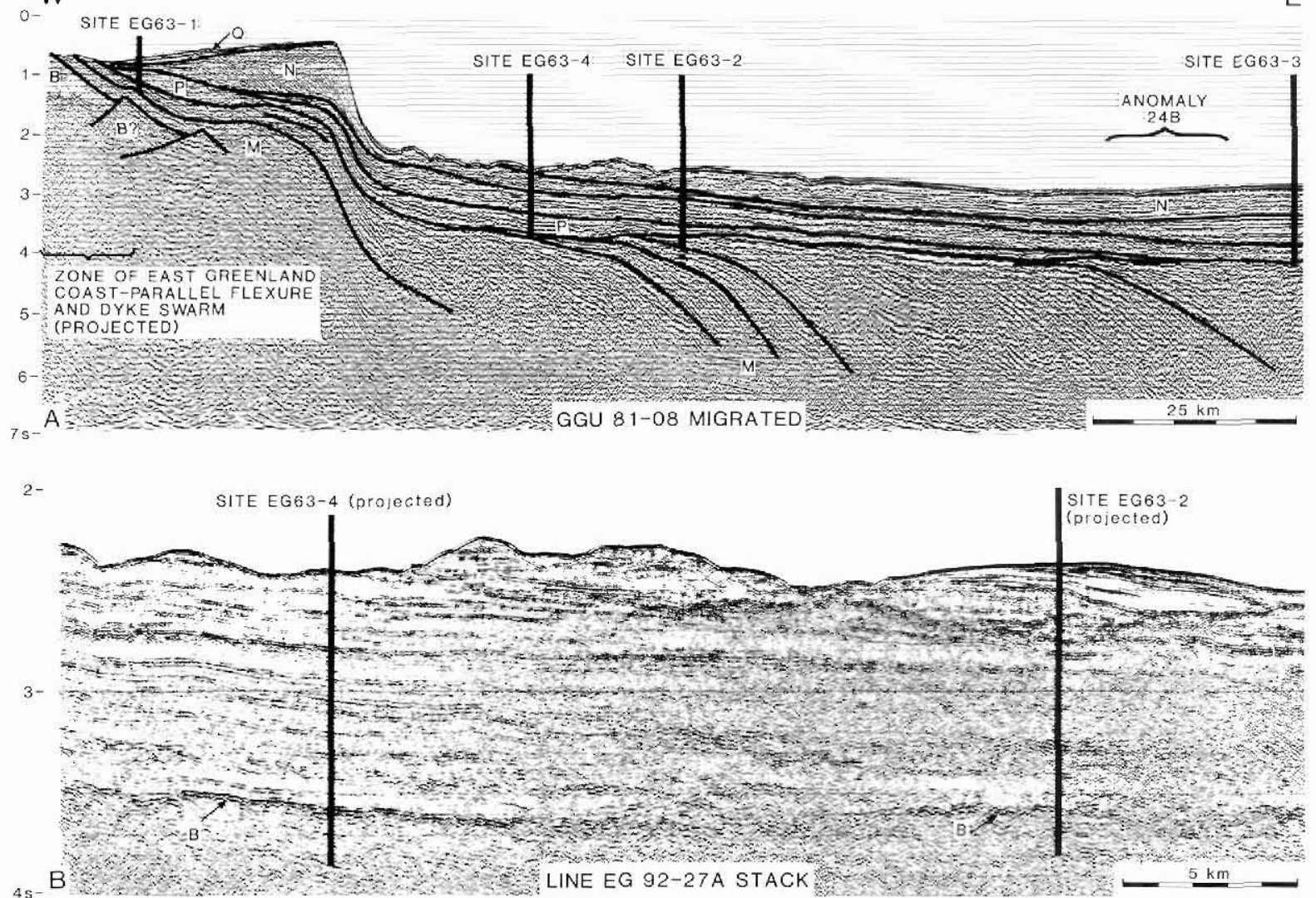

Fig. 2A. Multi-channel seismic line through the drill-sites EG63-1 and EG63-2 planned for ODP drilling Leg 152. Two more sites (EG63-3,4) are planned for possible future ODP Legs in order to complete the transect. Note how the planned four sites will provide a fairly complete sampling of the stratigraphically extremely thick igneous sequence. B: Continental basement: M: Multiple; N: Neogene sediments; P: Paleogene sediments; Q: Quaternary. The strongly prograded part of the Neogene shelf sediments may have a glacial origin. Location of seismic line shown in Fig. 3.

B. Preliminary stack from the 1992 high resolution seismic survey. Note the much improved vertical resolution of these data compared to the older. deep MCS data (Fig. 2A). B: Volcanic basement (top of seaward-dipping reflectors). Line parallel and close to deep MCS line in Fig. 2A.

extruded, basaltic lavas. Not only do these thick lava sequences represent an extremely high volcanic productivity, but they also seem to be underlain by rather thick crust which in its lowermost part may have been underplated. On the basis of all these new observations it was proposed that this new type of rifted margin - the volcanic rifted margin - was perhaps related to mantle plume activity (c.g. White \& McKenzie, 1989).

There are several schools of thought concerning if and how mantle plumes are present and interact with the lithosphere during continental break-up (Mutter et al., 1988; Griffiths \& Campbell, 1990; Duncan \& Richards, 1991; Hill, 1991). A number of ODP drilling proposals (including two from GGU; H. C. Larsen et al. 1991a, b) were prepared by various research groups in order to address the problem of the formation of volcanic margins. These proposals were merged into a coherent ODP multi-leg drilling programme which selected the South-East Greenland margin as the preferred location for drilling a global reference transect across this type of margin (H. C. Larsen et al., 1991c, d).

\section{Planned ODP drilling}

Drilling on the South-East Greenland continental shelf and rise by the Ocean Drilling Program (ODP) is planned for October-November 1993 (ODP drilling Leg 152). The planned ODP drilling will primarily address fundamental questions concerning volcanic rifted margin formation by drilling through the entire post break-up sequence and sampling the underlying volcanic basement; hopefully it will be possible to distinguish between competing models for their formation 


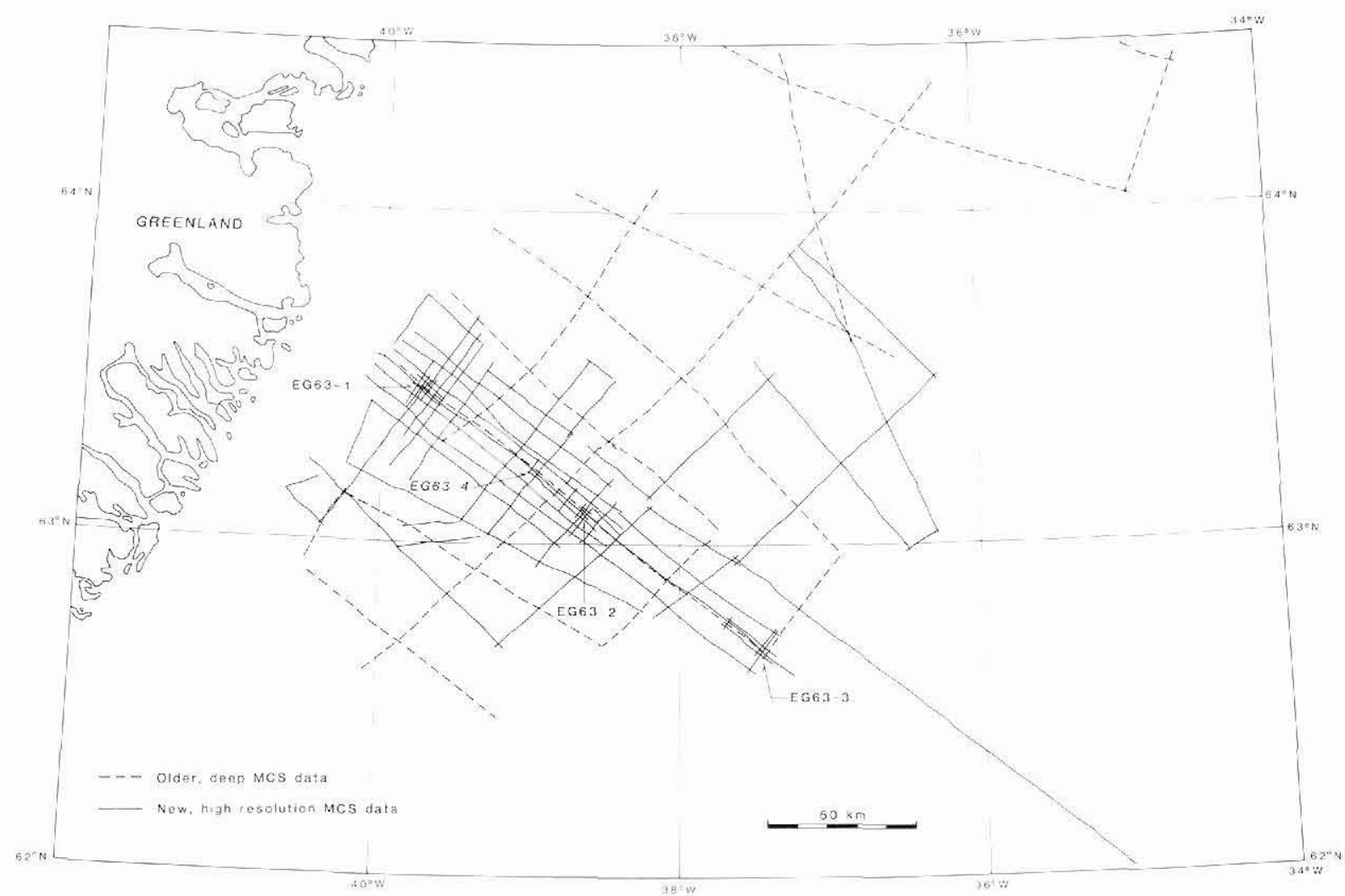

Fig. 3. Preliminary track map of the 1992 site survey. Older, deep seismic lines and positions of planned ODP drill sites are also shown.

(H. C. Larsen et al., 1991c, d). Leg 152 is expected to drill $250-500 \mathrm{~m}$ into volcanic basement at two sites (sites EG63-1, 2 in Figs 2A, 3). This will provide both a coarse sampling of the general development of volcanism from its initial stage (site EG63-1) through to steady state conditions (EG63-2) and a more detailed stratigraphic sampling by the deep basement penetration through many successive lava flows.

For possible subsequent ODP-Legs, drilling of three to four more sites on the South-East Greenland margin is planned, as well as sites on the Voering Plateau, in order to explore possible systematic spatial variabilities related to offset from a supposed plume centre or variations in lithospheric setting. So far only Leg 152 is scheduled for drilling.

Major objectives of Leg 152 drilling are the timing and rate of early igneous crust formation, the syn-constructional flexural deformation rate and flexural strength of the igneous crust exhibiting seaward-dipping reflectors, the distribution in time and space of the apparent thermal anomaly associated with this kind of margin development, magma sources (including pos- sible plume components), magma emplacement and post-constructional subsidence of the volcanic edifice.

Secondary objectives are the subsidence and infill of the basin between the East Greenland margin and the Reykjanes Ridge south of the Iceland-Greenland Ridge, the Neogene overflow of Greenland Sea water across the gateway between Iceland and Greenland (H. C. Larsen, 1990), and the stratigraphic response on the shelf and in deeper water to late Neogene climatic changes (Funder \& H. C. Larsen. 1989).

GGU scientists have been involved as proponents for Leg 152, are involved as Co-Chief and shipboard scientist, and provide the required site-survey work. Also, though peripheral to GGU's petroleum geological activities, the planned drilling and associated geophysical site-surveying will provide ties and dating of the seismic sequences present off South-East Greenland. This will be of great importance to the systematic mapping of this part of the Greenland shelf and rise. 


\section{Site-survey activities}

In 1992 a high resolution seismic survey was carried out off South-East Greenland in August-September (Fig. 3). Approximately $2800 \mathrm{~km}$ of 24 channel seismic data were acquired partly as site specific data through or very close to the planned drill sites, and partly as more regional data providing accurate seismic stratigraphic control in the region surrounding the drill sites. A similar survey is planned for 1993. This will include extension of the regional coverage, specific site-surveying of planned ODP volcanic margin drill-sites not included in Leg 152, and surveying for potential drill-sites addressing the stratigraphic response to late Neogene climatic changes. These activities will take place as part of a joint project between the Geological Survey of Denmark, the Marine Geological Department of the University of Aarhus and GGU. The project is supported by the Danish Natural Science Research Council.

The 1992 seismic survey was carried out from the Faeroese research vessel R/V Magnus Heinason (B. Larsen, 1992). The recording equipment consisted of a 24 group, $150 \mathrm{~m}$ long streamer and a 24 channel, Geometrics digital recording system. A point source array of four small sleeve guns with a total volume of 160 cubic inches was fired every 12.5 metres (shelf) or 18.7 metres (deep water) and recorded to between 2 and 3 seconds (two-way travel time) below the sea-floor. Preliminary processed data show excellent resolution and penetration to volcanic basement (Fig. 2B), except in areas of strong and highly disturbing sea-bed multiples. Penetration to $c .0 .5$ seconds into the volcanic rocks can be seen in areas of low noise (multiples or sea-bed diffractions). The seismic data will be processed to final stack and migrated during the spring of 1993.

In addition to the seismic data $12 \mathrm{kHz}$ echo sounding and marine magnetics were carried out during the entire 1992 survey. Bottom sampling on the shelf close to the planned drill site yielded glaciomarine sands and silts with small pebbles (B. Larsen, 1992).

Acknowledgements. The NAD seismic programme, carried out from 1980-1985, was funded by the Danish Ministry of Energy and the EEC energy programme. The present understanding of the South-East Greenland margin would not have been possible without extensive national and international teamwork. I thank the ODP for support of the scientific planning process within this research area (North Atlantic Rifted Margin Detailed Planning Group) and for having invited me to be Co-Chief Scientist on the first drilling Leg of volcanic rifted margin drilling. The site-survey in 1992 was only made possible by the kind collaboration of $\mathbf{H}$. Lykke-Andersen, P. Trinhammer and S. Behrendt Jensen, Marine Geological Department, University of Aarhus (seismic recording, technical supervision and processing), M. S. Andersen and B. Larsen, Geological Survey of Denmark (airguns and cruise leadership) and $\mathrm{H}$. Hirschleber, University of Hamburg (air-compressor). The site-survey and H. C. Larsen's participation in the ODP are funded by the Danish Natural Science Research Council.

\section{References}

Brooks, C. K. 1973: Rifting and doming in southern East Greenland. Nature Phys. Sci. 244, 23-25.

Brooks, C. K. 1979: Geomorphological observations at Kangerdlugssuaq, East Greenland. Meddr Grønland Geosci. 1, 21 pp.

Coffin, M. F. \& Eldholm, O. (ed.) 1991: Large igneous provinces, JOI/USSAC Workshop Report. The University of Texas at Austin Institute for Geophysics Technical Report 114, 74 pp. + app.

Duncan, R. A. \& Richards, M. A. 1991: Hotspots, mantle plumes, flood basalts, and true polar wander. Rev. Geophys. 29, 31-50.

Eldholm, O., Thiede, J. \& Taylor, E. 1989: Evolution of the Vøring Volcanic Margin. In Eldholm, O. et al.: Proc. ODP, Sci. Results, College Station (Ocean Drilling Program) 104, 1033-1065.

Funder, S. \& Larsen, H. C. 1989: Quaternary geology of the shelves adjacent to Greenland. In Fulton, R. J. (ed.) Quaternary geology of Canada and Greenland. The geology of North America, Vol. K, 769-772. Boulder: Geological Society of America.

Griffiths, R. W. \& Campbell, I. H. 1990: Stirring and structure in mantle starting plumes. Earth Planet. Sci. Lett. 99, 66-78.

Hill, R. I. 1991: Starting plumes and continental break-up. Earth Planet. Sci. Lett. 104, 398-416.

Hinz, K. 1981: A hypothesis on terrestrial catastrophes. Wedges of very thick oceanward dipping layers beneath passive continental margins - their origin and paleoenvironmental significance. Geol. Jahr. Reihe E, Geophysik 22, 3-28.

Larsen, B. 1992: Seismiske undersøgelser. Togtrapport $\emptyset$ stgrønland $63^{\circ} \mathrm{N}$. NARM SITE SURVEY 1992. M/T Magnus Heinason 1992. DGU Datadokumentation 18, $31 \mathrm{pp}$.

Larsen, H. C. 1978: Offshore continuation of East Greenland dyke swarm and North Atlantic Ocean formation. Nature, Lond. 274, 220-223.

Larsen, H. C. 1983a: Marine geophysical investigations offshore East Greenland. Rapp. Grønlands geol. Unders. 115, 93-100.

Larsen, H. C. 1983b: Rifting and post-rift vertical movements of East Greenland. Prog. Abstr. 18 General Assembly Inter-Un. Comm. Lith. (ICL), Hamburg, 1983, 52 only.

Larsen, H. C. 1985: Project NAD - East Greenland: an integrated aeromagnetic and marine project off the east coast of Greenland. Final report, Grønlands Geologiske Unders $\emptyset$ gelse, December 1985, $78 \mathrm{pp}$.

Larsen, H. C. 1990: The East Greenland shelf. In Grantz, A., Johnson, L. \& Sweeney, J. F. (ed.) The Arctic Ocean region. The geology of North America, Vol. L, 185-210. Boulder: Geological Society of America. 
Larsen, H. C. \& Jakobsdóttir, S. 1988: Distribution, crustal properties and significance of seawards dipping sub-basement reflectors of E Greenland. In Morton, A. C. \& Parson, L. M. (ed.), Early Tertiary volcanism, NE Atlantic. J. geol. Soc. Lond. Spec. Publ. 39, 95-114.

Larsen, H. C., Brooks, C. K., Cox, K. G., Larsen, B., Larsen, L. M., Morton, A. G. \& Nielsen, T. D. F. 1991a: Drilling the continent-ocean transition on the SE Greenland volcanic rifted margin: linking continental flood basalts to seaward dipping reflectors. ODP-drilling proposal 393, GGU, Copenhagen. $12 \mathrm{pp}$. + figures.

Larsen, H. C., Chalmers, J. A., Cox, K. G., Hald, N., Keen, C., Larsen, L. M., Pedersen, A. K. \& Srivastava, S. D. 1991b: A mantle plume origin of the North Atlantic volcanic rifted margins: testing the model against geological data. ODP-drilling proposal 392 , GGU, Copenhagen. $10 \mathrm{pp} .+$ figures.

Larsen, H. C., Sawyer, D. S. \& the NARM-DPG 1991c: North Atlantic rifted margins detailed planning group report (executive summary). JOIDES Journal, XVII, 2, 24-26.

Larsen, H. C., Sawyer, D. S. \& the NARM-DPG 1991d: North Atlantic rifted margins detailed planning group report. JOIDES Office, September 1991. 81 pp. + 124 figures and appendices.

Mutter, J. C., Talwani, M. \& Stoffa, P. L. 1982: Origin of seaward-dipping reflectors in oceanic crust off the Norwegian margin by 'subaerial sea-floor spreading'. Geology $\mathbf{1 0}$, 353-357.

Mutter, J. C., Buck, W. R. \& Zehnder, C. M. 1988: Convective partial melting. 1. A model for the formation of thick basaltic sequences during the initiation of spreading. $J . g e$ ophys. Res. B93, 1031-1048.

Myers, J. S. 1980: Structure of the coastal dyke swarm and associated plutonic intrusions of East Greenland: Earth Planet. Sci. Lett. 46, 407-418.

Nielsen, T. F. D. 1978: The Tertiary dike swarm of the Kangerdlugssuaq area, East Greenland. Contrib. Mineral. Petrol. 67, 63-78.

Nielsen, T. F. D. \& Brooks, C. K. 1981: The E Greenland rifted continental margin: an examination of the coastal flexure. J. geol. Soc. Lond. 138, 559-568.

Roberts, D. G., Schnitker, D. et al. 1984: Init. Repts. DSDP Leg 81, US Government Printing Office.

Roberts, D. G., Coffin, M. F., Crane, K., Eldholm, O., Harry, D., Larsen, H. C., McNutt, M., Okay, N., Pedersen, T., Skogseid, J. \& Tucholke, B. 1991: Conjugate volcanic passive margin and oceanic plateau development. In Coffin, M. F. \& Eldholm, O. (ed.) Large igneous provinces: JOI/ USSAC Workshop Report. The University of Texas at Austin Institute for Geophysics Technical Report 114, 29-46.

Smythe, D. K. 1983: Faeroe-Shetland escarpment and continental margin north of the Faeroes. In Bott, M. H. P., Saxov, S., Talwani, M. \& Thiede, J. (ed.) Structure and development of the Greenland-Scotland Ridge; new methods and concepts, 109-120. New York: Plenum Press.

Wager, L. R. 1934: Geological investigations in East Greenland. I. General geology from Angmagsalik to Kap Dalton. Meddr Grønland 105(2), 1-46.

Wager, L. R. \& Deer, W. A. 1938: A dyke swarm and coastal flexure in East Greenland. Geol. Mag. 75, 39-46.

White, R. S. \& McKenzie, D. 1989: Magmatism at rift zones: the generation of volcanic continental margins and flood basalts. J. geophys. Res. B94, 7685-7729.

H. C. L., Geological Survey of Greenland, Copenhagen. 